\title{
PROCRASTINATION: RELATIONS WITH MOOD, SELF-EFFICACY, PERCEIVED CONTROL AND TASK DEMANDS
}

\author{
Marijana Šuvak-Martinović \\ Department of Psychology, Faculty of Humanities and Social Sciences, University of Mostar \\ Matice hrvatske bb, 88000 Mostar, Bosnia \& Herzegovina \\ marijana.sunjic@gmail.com \\ Ivona Čarapina Zovko \\ Department of Psychology, Faculty of Humanities and Social Sciences, University of Mostar \\ Matice hrvatske bb, 88000 Mostar, Bosnia \& Herzegovina \\ carapina.ivona@gmail.com
}

\begin{abstract}
Summary
Procrastination is widely recognized as a motivational problem, but its nature is still not entirely understood, especially in the work domain. Procrastination in the execution of everyday work tasks could be motivated by both mood repair and predictor of poor mood. It could also be related to task characteristics, like averseness or demands. The aim of this study is to examine the relation between procrastination, levels of self-efficacy, perceived job demands and control, and symptoms of anxiety and depression. This study was conducted on a sample of 70 teaching assistants, the employees of a small university. The data was collected using Avoidance reactions to a deadline scale, DASS, Self-efficacy scale and Job demand-control scale. Correlation results indicated that self-efficacy and perceived job control were negatively, and job demand positively related to proneness to procrastination. Furthermore, individuals with more symptoms of anxiety and depression tended to procrastinate more. Perceived job control is the single relevant predictor of delaying job-related tasks and activities. The findings clearly suggest that job control deserves additional attention when it comes to the prediction of workplace procrastination.
\end{abstract}

Key words: procrastination, job control, job demands, self-efficacy, affect

\section{INTRODUCTION}

Procrastination is widely recognized as a motivational problem, but it is still not entirely understood. Steel (2007, p. 66) defines procrastination as a form of selfregulatory failure, where we voluntarily delay an intended course of action despite expecting to be worse off for the delay. This self-regulatory deficit includes the fail- 
ure to motivate oneself to begin and execute a wanted activity in the preferred or expected period (Senecal, Koestner \& Vallerand 1995). Van Eerde (2000) defines it as the avoidance of the implementation of an intention. It may ultimately lead to guilt, regret, and disappointment with oneself. Pychyl \& Flett (2012) find numerous factors operating in this maladaptive behavioral pattern: motivational, affective, cognitive, and behavioral. Some recent studies emphasize the vital role of metacognitive beliefs about procrastination (e.g. the uncontrollability of procrastination) in its persistence (Fernie, Spada, Nikčević, Georgiou \& Moneta, 2009; Fernie, Bharucha, Nikčević, Marino \& Spada, 2017). Finally, recent views on procrastination underscore emotional regulation as being fundamental in procrastination (Rebetez, Rochat \& Van Der Linden, 2015; Sirois \& Pychyl, 2013).

In the search for the causes and correlates of procrastination, researchers have addressed both task characteristics and individual differences. In some older studies, authors point out bad time management or low task prioritizing skills (e.g. Lay \& Schouwenbourg, 1993; Van Eerde, 2003b). Some authors (e.g. Díaz-Morales, Cohen \& Ferrari, 2008; Schouwenburg \& Lay, 1995; Watson, 2001; Steel \& Klingsieck, 2016) find procrastination to be related to conscientiousness and, to a lesser extent, to neuroticism, and some even consider it to be a lower-order trait (e.g. Watson, 2001). Van Eerde (2003a) reports the strongest correlations with conscientiousness (mean $r=-0.61$ ) and self-efficacy (mean $r=-0.44$ ). Watson (2001) finds procrastinators more sensitive to how enjoyable a task is. In a large meta-analysis, Steel (2007) finds task averseness (difficult, boring or frustrating tasks), task delay, self-efficacy, impulsiveness, and facets of conscientiousness (self-control, distractibility, organization, achievement motivation) to be consistent predictors of procrastination tendency. Self-efficacy has been widely recognized as a strong predictor of procrastination in various life domains (e.g. Seo, 2008; Sirois, 2004), and thus related to one of the strongest motives to procrastinate: fear of failure (Schouwenburg, 1992). Furthermore, many researchers find procrastination related to or even a form of self-handicapping tendency (Ferrari \& Tice, 2000; Van Eerde, 2000), which is thought to have a self-esteem protecting function. In addition, self-efficacy deserves special attention in the work context because of its relation to work-related performance (Stajkovic \& Luthans, 1998). Judge, Jackson, Shaw, Scott \& Rich (2007) found the unique contribution of self-efficacy to work-related performance when controlling for personality (the Big five traits), intelligence or general mental ability, and job or task experience.

While personality traits, motives such as fear of failure (even perfectionist standards) and affects have received much scholarly attention (especially in the educational context), rebellion against the control of others or lack of perceived control has not. Lack of job control could be interpreted as a specific, work-related self-efficacy. Working toward assigned goals (efficacy standards, deadlines) can be aversive (Tice, Bratslavsky \& Baumeister, 2001). In such situations, people may find it more enjoyable to engage in leisure activities (that are autonomous and in- 
trinsically motivated). Once again, the perception of low personal control can lead to a negative affect, and a negative affect (especially depression) can provoke perception of low control. In addition, delaying and thus piling-up work-related tasks might lead to the perception of low job control.

Studies on work-related procrastination are scarce. Nguyen, Steel \& Ferrari (2013) found that procrastination is associated with slightly lower salaries, shorter employment duration and higher chance of unemployment. Interestingly, procrastinators have a greater likelihood of having jobs with high constraints, such as those with low levels of autonomy. Van Eerde (2000) states that, when it comes to motivation at work, existing theories do not consider the question why people are motivated not to do things. The same author (2003b) also suggests the need to include individual workloads when predicting procrastination at work. When it comes to job demands, it is well known that procrastination creates time pressure, and this pressure can increase the perception of job demands. Still, it is quite possible that high job demands precede anxiety, bad mood and consequently the delaying of work tasks. Further investigation of the relation between job demands and delaying would be beneficial.

Negative affect can be both an antecedent and consequence of delaying the execution of a desired activity. In studies on student procrastination, those who procrastinate more tend to have a higher score on depression and both state and trait anxiety (Constantin, English \& Mazmanian, 2017; Senecal et al., 1995; Stöber \& Joormann, 2001; Van Eerde, 2003a; Watson, 2001). Although problematic levels of anxiety as an outcome define procrastination, procrastination is one way of temporarily evading anxiety. However, when the anxiety later resurfaces, its level is compounded. Constantin et al. (2017) found that rumination (negative, repetitive thoughts about the past) plays a key role in links between anxiety and depression on the one hand and procrastination on the other. Students with higher levels of depression and anxiety engage in dwelling more on negative feelings and self-relevant information from the past, which contributes to delaying tasks and responsibilities. With respect to the impact of mood, Tice and colleagues stated that individuals tend to repair mood by procrastinating in the short run and that negative moods predispose failure of self-regulation (Tice \& Bratslavsky, 2000; Tice et al., 2001). Procrastination in the execution of everyday work tasks could be motivated by temporary mood repair (to escape or avoid unpleasant feelings) and be a predictor of negative affect in the long run.

Milgram, Mey-Tal \& Levison (1998) put the above-mentioned correlates of procrastination in order by postulating the appraisal-anxiety-avoidance model of procrastination, based on Lazarus \& Folkman's theory of coping in stressful situations. When people find a situation (e.g. work task) threatening and perceive their resources inadequate (e.g. low self-efficacy and/or control), stress or anxiety ensues, and they try to escape the situation. Escape occurs in the form of putting off doing 
anxiety-inducing tasks, and results in temporary relief. Task postponement is negative reinforcement, thus enabling task postponement to continue.

In this study, we tried to combine the perception of control and job demands (as Van Eerde (2003b) suggested) with self-efficacy, depression and anxiety symptoms (from Milgram's above-mentioned model) in predicting procrastination in an important real-life domain: the work domain.

\section{SUBJECTS AND METHODS}

\section{Participants}

The study was conducted on a relatively small sample of 70 teaching assistants (44 women, 24 men, two did not respond to the questionnaire), employees of a small university (the average age was 30.22 years, $\mathrm{SD}=1.87$ ). Of the total participants, 46 were employed full time, 22 part-time, and two offered no answer. Nine of the full-time employees were additionally employed part-time, and most (65) were postgraduate students. 29 were married, and 19 had children. In order to examine the potential differences in procrastination according to socio-demographic characteristics, we applied the t-test. The results showed that there were no differences (male vs. female $\mathrm{t}=0.09, \mathrm{p}=0.54$; additional part-time employment vs. non-additional part-time employment $\mathrm{t}=1.11, \mathrm{p}=0.12$; full-time employment vs. part-time employment $\mathrm{t}=1.14, \mathrm{p}=0.70$; married vs. non-married $\mathrm{t}=1.46, \mathrm{p}=0.71$; those who have children vs. those who do not have children $\mathrm{t}=0.58, \mathrm{p}=0.85$ ).

The usual tasks and responsibilities of the teaching assistants include assisting faculty members, helping in the preparation of lectures, exercises, and seminars, maintaining regular office hours to meet students, administrating and grading exams. We chose this sample not just for convenience, but because teaching is a profession with a moderate amount of job autonomy, that leaves enough room for procrastination. The participants were recruited using the snowball sampling procedure outside the institution. They were familiarized with the objective of the study, and all of them gave their informed consent. Some of them completed questionnaires in groups and others individually. The participants completed the questionnaires anonymously.

\section{Method}

Data was collected through a questionnaire composed of several self-evaluation instruments.

Demographic data were collected for each participant, including sex, age, professional status at the institution, employment status, other part-time employment, 
Ph.D. student status, marital status and children. We tried to cover some extra role activities that could lead to a higher workload (Ph.D. student status, other part-time employment) or role conflict (e.g. married, children).

The Avoidance Reactions to a Deadline Scale (Van Eerde, 2003b) was used for the assessment of the tendency to procrastinate. This is a short, eight-item scale (e.g. I convince myself that there are other things to be done first), where participants indicate to what extent they agree with the given statements $(1=$ not at all, $5=$ completely). The scale had an acceptable level of internal consistency (Cronbach's $\alpha=0.86$ ).

The Job Demand-Control Scale (Gregov \& Šimunić, 2012) is a 12-item scale based on Karasek's model. A scale from 1 ("not at all") to 7 ("completely agree") was used to state to what extent participants agreed with the given statements. Dimensions were not combined (as a measure of job stress) but used separately for assessment of perceived control (five items, e.g. I am completely in control in managing my workload) and job demands/ workload (seven items, e.g. My job is difficult due to many unpredictable situations). Both dimensions showed an acceptable level of internal consistency (Cronbach's $\alpha=0.81$ and 0.75 respectively).

Self-efficacy was measured using the General Self-Efficacy Scale (Schwarzer, Bäsler, Kwiatek, Schröder \& Zhang, 1997; adapted by Ivanov \& Penezić, 2002). The scale consists of 10 items (i.e. I can solve most of my problems if I put enough effort in it), measuring the sense of efficacy in potentially stressful situations. Participants rated to what extent the given statement reflected their experience on a scale from 1 (not at all) to 5 (completely). The internal reliability of this scale is high (Cronbach's $\alpha=0.82$ ).

Symptoms of depression and anxiety were measured using an adapted Croatian version (Reić Ercegovac \& Penezić, 2012) of Lovibond \& Lovibond's Depression Anxiety Stress Scale (DASS). The scale consists of 42 items, 14 measuring depression (i.e. I feel that there is nothing to be happy about), 14 measuring (state) anxiety (i.e. I feel highly-strung) and finally 14 measuring stress symptoms experienced in the previous month (stress symptoms were not used for further analysis). Items were rated on a scale from 0 ("never") to 3 ("always"). The internal consistency, computed as Cronbach's $\alpha$, was quite high: 0.87 for depressive and 0.91 for anxiety symptoms.

All instruments were adapted to the Croatian language, and as such previously used for research purposes.

\section{Statistical analysis}

Descriptive analysis was performed (means and standard deviation, median and percentages where needed). Pearson correlation tests were used to test relationships between procrastination and self-efficacy, perceived job control and demands, and 
Spearman's correlation coefficient was calculated for depression and anxiety symptoms. For the prediction of the main criteria variable, procrastination tendency, standard regression analysis was carried out.

\section{RESULTS}

Descriptive data for major variables are shown in Table 1. Procrastination, job demands, and control as well as self-efficacy have a normal distribution. Symptoms of depression and anxiety show positively skewed distributions, which was expected as the sample was non-clinical.

The results of zero-ordered correlation (Pearson's and Spearman's where appropriate) show a small but significant positive correlation between job demands and procrastination. As expected, perceived job control and general self-efficacy are negatively related to procrastination. Individuals with more depression and anxiety symptoms are more prone to procrastinating.

The results of multiple regression analysis in which procrastination was used as a criterion variable are shown in Table 2. It seems that only perceived job control

Table 1. Average scores on scales and zero-ordered correlations between procrastination, job demands and control, general self-efficacy, and affect $(N=70)$

\begin{tabular}{lccccccccc}
\hline & $M$ & $S d$ & Range & 1 & 2 & 3 & 4 & 5 & 6 \\
\hline 1 Procrastination & 2.54 & 0.95 & $1-4.75$ & 1.00 & $0.28^{*}$ & $-0.36^{* *}$ & $-0.25^{*}$ & $0.52^{* *}$ & $0.45^{* *}$ \\
2 Job demands & 4.55 & 0.99 & $2.57-6.57$ & & 1.00 & $-0.23^{*}$ & $-0.29^{*}$ & $0.40^{* *}$ & $0.39^{* *}$ \\
3 Job control & 4.76 & 1.20 & $1-6$ & & & 1.00 & $0.23^{*}$ & $-0.45^{* *}$ & $-0.29^{*}$ \\
$\begin{array}{l}\text { 4 Self-efficacy } \\
\text { 5 Symptoms of } \\
\text { depression }\end{array}$ & 3.87 & 0.52 & $2-5$ & & & & 1.00 & $-0.36^{* *}$ & $-0.30^{*}$ \\
$\begin{array}{l}\text { 6 Symptoms of } \\
\text { anxiety }\end{array}$ & 0.52 & 0.39 & $0-3$ & & & & & 1.00 & $0.74^{* *}$ \\
\hline
\end{tabular}

$* p<0.05 ; * * p<0.01$

Table 2. Predictors of procrastination- results of standard regression analysis

\begin{tabular}{lccc}
\hline & $b$ & $S E b$ & $B$ \\
\hline Job demands & 0.14 & 0.13 & 0.14 \\
Job control & -0.38 & 0.16 & $-0.29^{*}$ \\
Self-efficacy & -0.10 & 0.12 & -0.07 \\
Symptoms of depression & -0.11 & 0.20 & -0.11 \\
Symptoms of anxiety & 0.27 & 0.22 & 0.27 \\
\hline
\end{tabular}

$$
\begin{array}{lll}
R^{2}=0.214 & \mathrm{~F}(5,64)=3.49 & \mathrm{P}<0.01
\end{array}
$$

$* p<0.05$ 
statistically contributes to explaining the tendency to procrastinate. It explained the $21.4 \%$ variance in the criterion. Based on the high correlation between depression and anxiety symptoms, the moderate correlations but a lack of contribution of depression and anxiety symptoms in predicting procrastination, high standard errors of regression and variance inflation factors for depression and anxiety symptoms (4 for both, which is a cause of concern in somewhat weaker models), we can suspect multicollinearity. When there is significant multicollinearity, regression coefficients can be quite unstable (Table 2). In addition, it is possible that they do not show a statistically significant individual contribution to explain the criteria variable (type II error), even if the correlation shows that they could be strong predictors (Table 2). This is particularly true for relatively small samples like ours (Mason \& Perreault, 1991).

\section{DISCUSSION}

The focus of this study was not to analyze the behavioral component of procrastination that can be interpreted as low conscientiousness or poor time management skills, as extensive research has already been conducted on these aspects of procrastination. We focused on work demands, the perception of job control and affective determinants of procrastination conceptualized as depression and anxiety symptoms. Most studies on procrastination have treated procrastination in students, trying to find its correlates in individual differences (Steel, 2007; Van Eerde, 2003a) and (poorer) academic performance (e.g. Kim \& Seo, 2015). Despite moderate correlations between negative affect and outcome variable, perceived job control is the only variable that achieved statistical significance in regression analysis. Low job control could be both a cause and a result of delaying job-related tasks. As Milgram et al. (1998) noted, people assess whether specific situations or daily work tasks can be controlled (or whether they could effectively deal with them) or not. If not, one will be motivated to put off anxiety provoking activities. This kind of negative reinforcement is the reason why people continue procrastinating, even if it results in great stress, anxiety and negative affect in the end. Yet, it is quite possible that proneness to procrastination, and consequential piling up of work-related tasks, can result in perceived low control in the workplace. Finally, it is not impossible that procrastination could also be a way of temporarily gaining some control.

In reference to the regression analysis results, we must stress the problem of multicollinearity of predictors. There are several ways to deal with this, and we will consider it in a further examination of the motives for procrastination. Of course, this is one more reason our results should be treated with some caution.

Besides job control, the tendency to delay activities including work tasks is connected to lower general self-efficacy and a higher workload. High job demands, similar to (low) job control, can be both the cause and the consequence of delaying 
tasks and activities. Again, similar to job control, delaying can be an appealing way of temporarily decreasing job demands, thus adding time pressure to previous demands. Self-efficacy has a relatively small correlation with procrastination, which was unexpected. This could be due to the general measure of self-efficacy, tapping the general belief that one can deal with unexpected circumstances in a satisfactory way. Of course, we could interpret the perception of job control as an indicator of specific, work-related self-efficacy. A positive correlation between procrastination and depression and anxiety symptoms exists in the professional context. When it comes to the relation of the (current) affective state, self-efficacy and procrastination, multiple paths are possible. Depression symptoms include a lack of energy and concentration, which makes the person prone to delaying tasks (Steel, 2007), even those that enhance psychological (e.g. well-being) or material (e.g. money) opportunities. Constant worrying and doubting (symptoms of anxiety) have a similar effect. Rumination (repetitive negative thoughts focused on the past) could explain relations between procrastination on the one hand, and both depression and anxiety on the other (Constantin et al., 2017). Tice et al. (2001) suggest that, when affect regulation and impulse control are in conflict (e.g. when a person in a negative, depression-like mood or when feeling anxious faces an academic or work-related duty, especially a demanding/aversive one), affect regulation "wins". According to them, when people feel acutely bad, they generally wish to feel better, and this wish is often urgent... emotional distress may, therefore, work against the usual pattern of impulse control because distress promotes a short-term focus, whereas impulse control requires a long-term one (Tice et al., 2001, p. 53). Negative affects thus impair one's motivation to regulate one's own behaviors in a "standard way", and this misregulation is reflected in procrastination. In the end, procrastination yields mood impairment (symptoms of depression and anxiety), and the process continues repeating itself. Rebetez et al. (2015) found a subgroup of procrastinators (among students) with poor emotion regulation that may prioritize negative mood management over long-term goals. Sirois \& Pychyl (2013) clearly state that short-term mood repair underlies this self-regulatory failure. They find temporal perspective especially important because the consequences of procrastinating must be fully borne by "the future self". Thus, temporal understanding of self and the mood-regulating processes involved in goal pursuit are crucial in understanding procrastination. To conclude on this, the discrepancy between work intentions and work actions could both precede but also result in negative affect.

How to deal with procrastination in the workplace? In one quasi-experimental study Van Eerde (2003b) finds that time management training helps in decreasing avoidance behavior and consequential worrying. It could certainly help in gaining control over job tasks, too. This is especially true for the effective execution of multiple goals. The current study is correlational, so one should be careful not to draw conclusions about a causal relationship. Our results suggest that job control needs 
additional attention when it comes to the prevention of delayed tasks and delay in fulfilling obligations.

\section{Limitations}

Unfortunately, this study does not allow us to conclude whether procrastination precedes, results, or overlaps with depression and anxiety symptoms, or whether it precedes or results in low perceived job control. This is a cross-sectional, correlational, self-report study and as such has many limitations. However, it stresses the importance of studying work-related procrastination. A longitudinal (particularly in the case of a negative affect-procrastination causal relation, ideally in first-time employees) or, better yet, quasi-experimental study (potentially beneficial in assessing procrastinators' vs. non-procrastinators' reactions to different job control and demands variations) would offer further clarification on these relations.

\section{CONCLUSIONS}

Perception of job control plays a significant role in predicting the delaying of job-related tasks and activities, where employees with lower job control tend to procrastinate more in the workplace. This finding (along with significant relations between procrastination, negative affect, and job demands) has implications for both theory and practical interventions (e.g. developing strategies to feel in control) in dealing with intentional but unpleasant and potentially harmful delaying.

\section{REFERENCES}

Constantin, K., English, M. M., \& Mazmanian, D. (2017). Anxiety, Depression, and Procrastination Among Students: Rumination Plays a Larger Mediating Role than Worry. Journal of Rational-Emotive \& Cognitive-Behavior Therapy, 36(1), 15-27.

Díaz-Morales, J. F., Cohen, J. R. \& R. Ferrari, J. R. (2008). An integrated view of personality styles related to avoidant procrastination. Personality and Individual Differences, $45,554-558$.

Fernie, B. A., Bharucha, Z., Nikčević, A. V., Marino, C., \& Spada, M. M. (2017). A Metacognitive model of procrastination. Journal of affective disorders, 210, 196-203.

Fernie, B. A., Spada, M. M., Nikčević, A. V., Georgiou, G. A., \& Moneta, G. B. (2009). Metacognitive beliefs about procrastination: Development and concurrent validity of a self-report questionnaire. Journal of Cognitive Psychotherapy: An International Quarterly, 23(4), 283-293.

Ferrari, J.R. \& Tice, D.M. (2000). Procrastination as a self-handicap for men and women: a task-avoidance strategy in a laboratory setting. Journal of Research in Personality, (34), 73-83. 
Gregov, LJ. \& Šimunić, A. (2012). Skala psiholoških zahtjeva i kontrole posla. In: Proroković A., Ćubela Adorić V., Penezić Z. \& Tucak Junaković I. (Ed.). Zbirka psihologijskih skala i upitnika, Svezak 6 (pp. 43-48). Zadar: University of Zadar.

Ivanov, L. \& Penezić, Z. (2002). Skala opće samoefikasnosti. In: Lacković-Grgin, K., Proroković, A., Ćubela, V. \& Penezić, Z. (Ed.). Zbirka psihologijskih skala i upitnika, Svezak 1 (pp. 6-7). Zadar: University of Zadar

Judge, T. A., Jackson, C. L., Shaw, J. C., Scott, B. A. \& Rich, B. L. (2007). Self-Efficacy and Work-Related Performance: The Integral Role of Individual Differences. Journal of Applied Psychology, 92(1), 107-127.

Kim, K. R. \& Seo, E. H. (2015). The relationship between procrastination and academic performance: A meta-analysis. Personality and Individual Differences (82), 26-33.

Lay, C.H. \& Schouwenburg, H.C. (1993). Trait procrastination, time management, and academic behavior. Journal of Social Behavior and Personality, 8(4), 647-662.

Mason, C.H. \& Perreault, W.D. (1991). Collinearity, Power, and Interpretation of Multiple Regression Analysis. Journal of Marketing Research, 28(3), 268-280.

Milgram, N., Mey-Tal, G. \& Levison, Y. (1998). Procrastination, generalized or specific, in college students and their parents. Personality and Individual Differences, 25, 297-316.

Nguyen, B., Steel, P., \& Ferrari, J. R. (2013). Procrastination's Impact in the Workplace and the Workplace's Impact on Procrastination. International Journal of Selection and Assessment, 21(4), 388-399.

Pychyl, T. A., \& Flett, G. L. (2012). Procrastination and self-regulatory failure: An introduction to the special issue. Journal of Rational-Emotive \& Cognitive-Behavior Therapy, 30, 203-212.

Rebetez, M. M. L., Rochat, L., \& Van der Linden, M. (2015). Cognitive, emotional, and motivational factors related to procrastination: A cluster analytic approach. Personality and Individual Differences, 76, 1-6.

Reić Ercegovac, I. \& Penezić, Z. (2012). Skala depresivnosti, anksioznosti i stresa (DASS). In: Proroković, A, Ćubela Adorić, V, Penezić, Z. \& Tucak Junaković, I. (Ed.). Zbirka psihologijskih skala i upitnika, Svezak 6 (pp. 15-22). Zadar: University of Zadar.

Seo, E. (2008). Self-efficacy as a mediator in the relationship between self-oriented perfectionism and academic procrastination. Social Behavior and Personality: An international journal, 36(6), 753-764.

Schouwenburg, H.C. (1992). Procrastinators and fear of failure: An exploration of reasons for procrastination. European Journal of Personality, 6, 225-236.

Schouwenburg, H. C. \& Lay, C. H. (1995). Trait procrastination and the Big Five factors of personality. Personality and Individual Differences, 18, 481-490.

Schwarzer, R., Bäsler, J., Kwiatek, P., Schröder, K. \& Zhang, J.X. (1997). The assessment of optimistic self-beliefs: Comparison of the German, Spanish, and Chinese versions of the general self-efficacy scale. Applied Psychology. An International Review, 46(1), 69-88.

Senecal, C., Koestner, R. \& Vallerand, R. (1995). Self-regulation and academic procrastination. Journal of Social Psychology, 135(5), 607-619.

Sirois, F.M. (2004). Procrastination and intentions to perform health behaviors: The role of self-efficacy and the consideration of future consequences. Personality and Individual Differences, 37(1), 115-128. 
Sirois, F., \& Pychyl, T. (2013). Procrastination and the priority of short-term mood regulation: Consequences for future self. Social and personality psychology compass, 7(2), 115-127.

Steel, P. (2007). The nature of procrastination. Psychological Bulletin, 133(1), 65-94.

Steel, P. \& Klingsieck, K. B. (2016). Academic Procrastination: Psychological Antecedents Revisited. Australian Psychologist, 51, 36-46.

Stajkovic, A.D. \& Luthans, F. (1998). Self-efficacy and work-related performance: A metaanalysis. Psychological Bulletin, 124(2), 240-261.

Stöber, J. \& Joormann, J. (2001). Worry, procrastination and perfectionism: Differentiating amount of worry, pathological worry, anxiety and depression. Cognitive Therapy and Research, 25(1), 49-60.

Tice, D.M. \& Bratslavsky, E. (2000). Giving in to feel good: The place of emotion regulation in the context of general self-control. Psychological Inquiry, 11, 149-159.

Tice, D.M., Bratslavsky, E. \& Baumeister, R.F. (2001). Emotional distress regulation takes precedence over impulse control: If you feel bad, do it! Journal of Personality and Social Psychology, 80(1), 53-67.

Van Eerde, W. (2000). Procrastination: Self-Regulation in Initiating Aversive Goals. Applied Psychology. An International Review, 49(3), 372-389.

Van Eerde, W. (2003a). A meta-analytically derived nomological network of procrastination. Personality and Individual Differences, 35(6), 1401-1418.

Van Eerde, W. (2003b). Procrastination at work and Time Management Training. Journal of Psychology, 137(5), 421-434.

Watson, D.C. (2001). Procrastination and the five-factor model: A facet level analysis. Personality and Individual Differences, 30(1), 149-158.

\title{
PROKRASTINACIJA: ULOGA PERCIPIRANE KONTROLE I ZAHTJEVA POSLA, SAMOEFIKASNOSTI I AFEKTIVITETA
}

\begin{abstract}
Sažetak
Prokrastinacija ili odugovlačenje široko je prepoznat motivacijski problem, no još uvijek nije jasno koji sve faktori utječu na njen nastanak i perzistenciju. Ovo posebno vrijedi za sklonost odugovlačenju u radnom kontekstu. Odugovlačenje u izvršavanju svakodnevnih radnih zadataka može biti motivirano i kratkotrajnom regulacijom raspoloženja, a može biti i prediktorom negativnog afektiviteta. Također, opravdano je pretpostaviti kako odugovlačenje ovisi i o nekim karakteristikama samog zadatka, kao što je, primjerice, zahtjevnost istog ili pak mogućnost kontrole. Cilj ovog istraživanja je ispitati odnos prokrastinacije s razinom samoefikasnosti, percepcijom zahtjeva i kontrole posla te sa simptomima anksioznosti i depresije. Istraživanje je provedeno na uzorku od 70 zaposlenika jednog manjeg sveučilišta (nastavnici u suradničkom zvanju). Kao mjere relevantnih konstrukata korištene su Skala izbjegavanja aktivno-
\end{abstract}


sti do krajnjeg roka, DASS skala, Skala samoefikasnosti te Skala zahtjeva-kontrole posla. Korelacijske analize su pokazale kako osobe s nižom samoefikasnošću, nižom percipiranom kontrolom posla te većom zahtjevnošću posla češće prokrastiniraju. Prokrastinacija je značajno povezana i s izraženošću simptoma depresije i anksioznosti. Regresijska analiza pokazuje kako je, u konačnici, percipirana kontrola posla jedini značajan prediktor odgađanja zadataka i aktivnosti vezanih uz posao. Rezultati jasno upućuju na to da kontrola posla zaslužuje dodatnu pažnju kada je u pitanju predikcija odgađanja izvršavanja obveza na radnom mjestu.

Ključne riječi: prokrastinacija, kontrola posla, zahtjevi posla, samoefikasnost, afekt 